\title{
A novel low uterine segment sandwich technique (Caliskan's technique) for the management of post- cesarean hemorrhage due to placenta previa accreta
} Plasenta previa accreta nedeniyle sezaryen sonrası kanama
yönetiminde yeni alt uterin segment sandviç tekniği (Çalışkan
tekniği)

\author{
(1) Eray Çalışkan1, (1) Bertan Akar², (1) Yasin Ceylan³, (1) Cihan Karadağ ${ }^{1}$ \\ 1Okan University School of Medicine, Department of Obstetrics and Gynecology, İstanbul, Turkey \\ 2İstinye University School of Medicine, Private Kocaeli Hospital, Clinic of Obstetrics and Gynecology, Kocaeli, Turkey \\ ${ }^{3}$ Kocaeli University School of Medicine, Department of Obstetrics and Gynecology, Kocaeli, Turkey
}

\begin{abstract}
Objective: Placenta previa (PP) and placenta accreta spectrum (PAS) disorders are major causes of postpartum hemorrhage (PPH). There is a variety of surgical management options with inexplicit reported success rates. Uterine sandwich is a combination of uterine compression sutures and intrauterine balloon placement to achieve hemostasis. The aim of this study was to present our experience of seven women managed with a novel "lower uterine sandwich" technique to control post-cesarean hemorrhage due to PP accreta.

Materials and Methods: Seven pregnant women diagnosed as having PP totalis accreta underwent a post-cesarean procedure combining bilateral ligation of the uterine artery, utero-ovarian artery, and internal iliac artery, Pereira compression sutures implemented on the uterine isthmus, Foley catheter placement into the lower uterine segment, and transvaginal cervical cerclage application, namely "Caliskan's uterine sandwich technique".

Results: All women included in this study had placental invasion abnormalities of varying degrees. Postoperative diffusion magnetic resonance imaging assessment revealed a completely normal and preserved uterine blood supply. All women menstruated regularly in their postoperative follow-up period and two women conceived again and delivered uneventfully. None of the patients experienced morbid complications nor required hysterectomy.

Conclusion: This novel procedure appears to be a plausible fertility and organ-preserving option in cases of intractable PPH, particularly in lower uterine segment bleeding. This uterine sandwich technique may allow physicians to manage massive hemorrhage due to PAS conservatively by preserving the uterus and its functions without major complications.
\end{abstract}

Keywords: Placenta previa, postpartum hemorrhage, uterine sandwich technique, uterine compression suture

$\ddot{\mathrm{O} z}$

Amaç: Plasenta previa (PP) ve plasenta akreta spektrum (PAS) bozuklukları postpartum kanamanın (PPK) başlıca nedenleridir. Açıkça bildirilmemiş başarı oranları ile çeşitli cerrahi tedavi seçenekleri vardır. Uterin sandviç, hemostazı sağlamak için uterin kompresyon sütürleri ve uterus içi balon yerleştirilmesinin bir kombinasyonudur. Bu çalışmanın amacı, PP akretaya bağlı sezaryen sonrası kanamayı kontrol etmek için yeni bir "alt uterin sandviç" tekniği ile tedavi edilen yedi kadına ilişkin deneyimimizi sunmaktır.

Gereç ve Yöntemler: PP totalis akreta tanısı konulan ve uterin arter, utero-ovaryan arter ve internal iliak arterin bilateral ligasyonu ile sezaryen sonrası işlem uygulanan yedi gebe kadın, uterin istmusa Pereira kompresyon sütürleri, Foley kateterinin alt uterin segmente yerleștirilmesi ve transvajinal servikal serklaj uygulaması, "Çalışkan'ın Uterin Sandviç Tekniği", yapıldı.

Bulgular: Bu çalışmaya dahil edilen tüm kadınlarda farklı derecelerde plasental invazyon anormallikleri vardı. Postoperatif difüzyon manyetik rezonans incelemesi, tamamen normal ve korunmuş uterus kan akımını ortaya çıkardı. Tüm kadınlar postoperatif takiplerinde düzenli olarak adet gördüler ve 2 kadın tekrar gebe kaldı ve sorunsuz doğum yaptı. Hastaların hiçbiri morbid komplikasyon yaşamadı ve histerektomi gerektirmedi.

PRECIS: A novel low uterne sandwich technique (Caliskan's technique) for placenta previa.

Address for Correspondence/Yazışma Adresi: Yasin Ceylan MD,

Kocaeli University School of Medicine, Department of Obstetrics and Gynecology, Kocaeli, Turkey

Phone: +90 5357489729 E-mail: md.yasinceylan@yahoo.com ORCID ID: orcid.org/0000-0001-5517-8461

Received/Geliș Tarihi: 30.03.2021 Accepted/Kabul Tarihi: 06.05.2021

${ }^{\oplus}$ Copyright 2021 by Turkish Society of Obstetrics and Gynecology

Turkish Journal of Obstetrics and Gynecology published by Galenos Publishing House 
Sonuç: Bu yeni prosedür, inatçı PPK olgularında, özellikle alt uterin segment kanamalarında makul bir doğurganlık ve organ koruma seçeneği gibi görünmektedir. Bu uterin sandviç tekniği, kliniğin uterusu ve fonksiyonlarını büyük bir komplikasyon olmaksızın koruyarak PAS’ye bağlı masif kanamaları konservatif olarak yönetmesine izin verebilir.

Anahtar Kelimeler: Plasenta previa, postpartum kanama, uterin sandviç tekniği, uterin kompresyon sutürü

\section{Introduction}

Postpartum hemorrhage (PPH) is a catastrophic complication of human birth, associated with blood transfusion, hysterectomy, maternal intensive care unit admission, septicemia, thrombophlebitis, and even an increased risk for maternal death ${ }^{(1-3)}$. PPH may emerge after vaginal delivery or cesaraen section, either as an early or a late complication of a number of obstetric conditions, including uterine atony, placental retention, abnormalities of placentation and placenta previa (PP). PP occurs in approximately 5 in every 1000 pregnancies and the incidence has severely increased through the last decades, possibly due to the increase in the rate of cesarean section deliveries ${ }^{(4-6)}$. On the other hand, PP is frequently complicated by invasion of placental villi beyond the decidua basalis causing placenta accreta or increta, referred to as placenta accreta spectrum (PAS) disorders ${ }^{(7)}$. These clinical situation suggests an association between endometrial damage and uterine scarring and subsequent previa ${ }^{(8)}$. Consequently, PP is associated with numerous adverse maternal outcomes, including massive hemorrhage, adjacent organ damage, and hysterectomy with loss of reproduction ${ }^{(4,5)}$.

The management of PPH due to PP or PAS consists of two therapeutic approaches; conservative and interventional approaches, and the latter should follow the former immediately in the event of failure. Conservative treatment of PPH due to PP consists of the administration of uterotonic drugs, uterine compression, and/or intrauterine balloon tamponade. When these initial therapeutic modalities fail, uterine compression sutures, uterine artery or internal iliac artery ligation, or radiologic embolization of the artery may be performed before hysterectomy is considered to control bleeding and to avoid maternal death ${ }^{(3,9,10)}$. However, hysterectomy results in the loss of reproduction function and arterial embolization techniques require high medical costs and sophisticated facilities. Thus, other minimally invasive procedures are required to treat $\mathrm{PPH}$ and preserve the uterus.

There is a variety of uterine compression sutures defined in the literature, including B-Lynch, Hayman and Cho sutures; however, all these suture techniques have some drawbacks ${ }^{(1,12)}$. The reported success rates of balloon tamponade methods are highly variable, possibly due to the heterogeneous causes of $\mathrm{PPH}$ and comorbidities accompanying the entity, thus these rates are not specific to $\mathrm{PP}^{(13,14)}$. Therefore, there are techniques combining uterus compression sutures and balloon tamponade, namely "uterine sandwich", in the literature, with the aim of defining a more successful and minimally invasive modality in controlling $\mathrm{PPH}^{(15-17)}$. The "sandwich" techniques combine the beneficial effects of "outer" compression sutures and "inner" pressure implicated by the intrauterine balloon placement. However, data on the literature of these techniques are quite scarce and there is no consensus on how and in whom uterine sandwich techniques should be used, as well as which uterine suture or balloon type should be employed.

The aim of this study was to present our experience on seven women who were managed conservatively with a novel "low uterine sandwich" technique to control post-cesarean hemorrhage due to PP accreta.

\section{Materials and Methods}

This retrospective descriptive clinical study involved seven pregnant women who were diagnosed as having PP totalis using two-dimensional ultrasonography and color Doppler evaluation (Voluson E8 probe) between January 2013 and December 2017 at Bahcesehir University School of Medicine, İstanbul, Turkey. The study was performed in accordance with the ethical standards for human research established by the Declaration of Helsinki and Good Clinical Practice guidelines and approved by the local Ethics Committee of Bahcesehir University School of Medicine. All patients provided written informed for the application of this technique.

During the study period, 171 women with the risk of or onset of postpartum bleeding underwent surgery by the Emergency Obstetric Team led by Eray Caliskan. Among these, 38 women were diagnosed as having PP and 25 had PP accreta spectrum. In addition to two peripheral vascular accesses made before the procedure, a central venous access was ensured in all women in the perioperative period. The skin incision was made through a Pfannenstiel incision. The fascia was cut transversely in the midline followed by a finger dissection to separate the rectus muscles and then opening the peritoneum. The myometrium was incised transversely at the lower segment (Munro-Kerr) in the midline, then opened and extended laterally with finger dissection despite anteriorly localized PP in six cases. The baby was delivered with external fundal pressure. The placenta was removed manually. After the removal of the placenta, 20 units of oxytocin (Synpitan Fort ampoule ${ }^{\circledR}$, Deva, Turkey) in $500 \mathrm{cc}$ Ringer's lactate, at the rate of $125 \mathrm{~mL} / \mathrm{h}$, was rapidly infused, in addition to intramuscular administration of $0.2 \mathrm{mg}$ methylergonovine maleate (Metiler ampoule ${ }^{\circledR}$, Adeka, Turkey). The procedures were performed in the following order:

1. Uterine arteries, utero-ovarian arteries and internal iliac arteries were ligated bilaterally using 1-0 polyglycolic acid suture (Vicryl ${ }^{\circledR}$; Ethicon, Sommerville, NJ, USA) on a $70-\mathrm{mm}$ circular needle (Figure 1).

2. An 18-French Foley catheter was introduced from the uterine incision, with its caudal end being placed in the vagina through 
the cervix, to be placed within the lower uterine segment and its balloon was inflated by 50-100 cc with warm saline solution. 3. The Foley catheter balloon was stabilized to the lower uterine segment at the isthmic level using circular Pereira sutures ${ }^{(18)}$ passing from the medial aspects of bilateral uterine arteries (Figure 2).

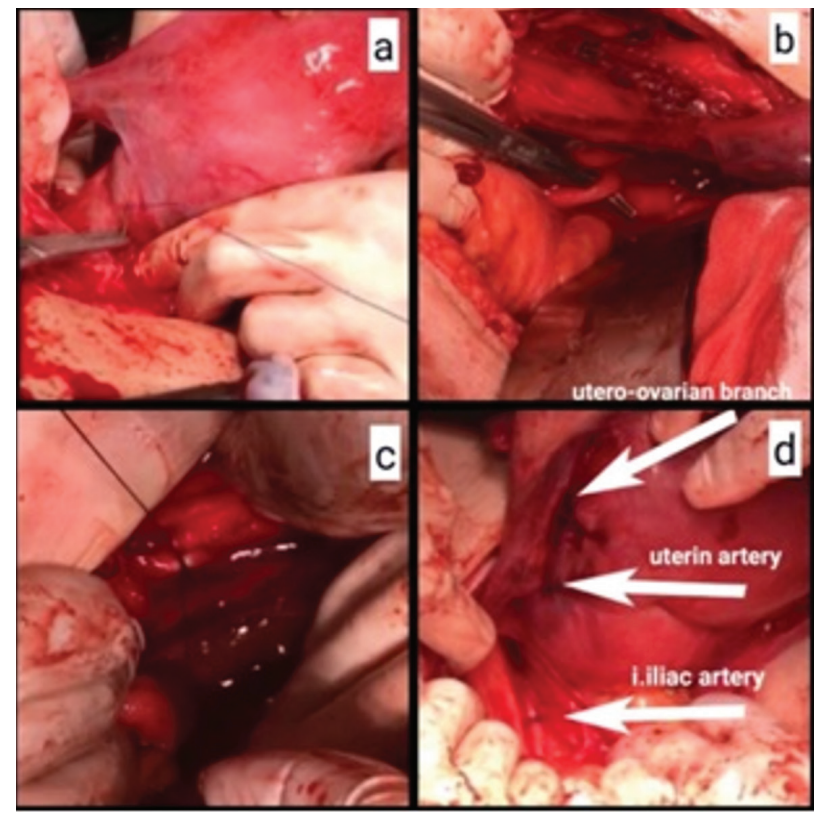

Figure 1. Systematic devascularization (a) Uterine artery ligation; (b), (c) Internal iliac artery ligation; (d) Uterine artery, utero-ovarian branches, internal iliac artery ligation

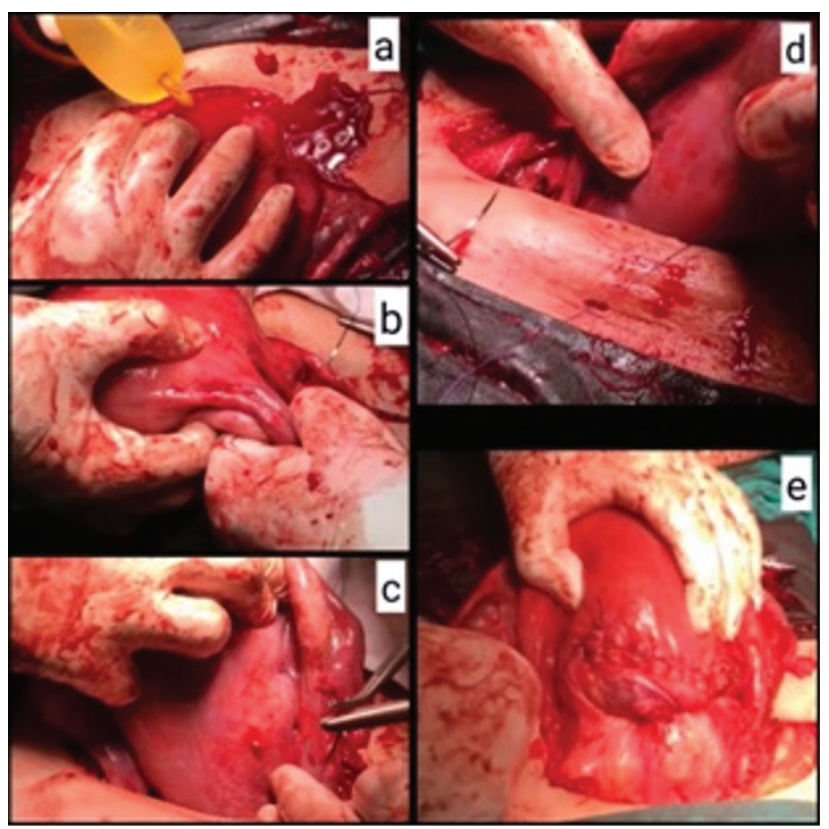

Figure 2. Balloon insertion into the lower uterine segment and the sandwich suture. (a) Foley catheter balloon; (b), (c), (d) Sandwich suture passing circularly from the medial aspects of bilateral uterine arteries; (e) The final view of the packaging suture
4. Cervical cerclage was applied transvaginally using 1-0 polyglycolic acid suture to keep the balloon in the uterine cavity and to prevent it from slipping downwards.

5. After the Hemovac drainage system was placed in the Douglas, the myometrial incision was closed with a double-layer suture with polyglycolic acid (Vicryl-Ethicon) 1-0 continuous locking suture.

The intraoperative surgical procedure and respective application of the procedure are illustrated with a stepwise explanation in figure 3 and figure 4 .

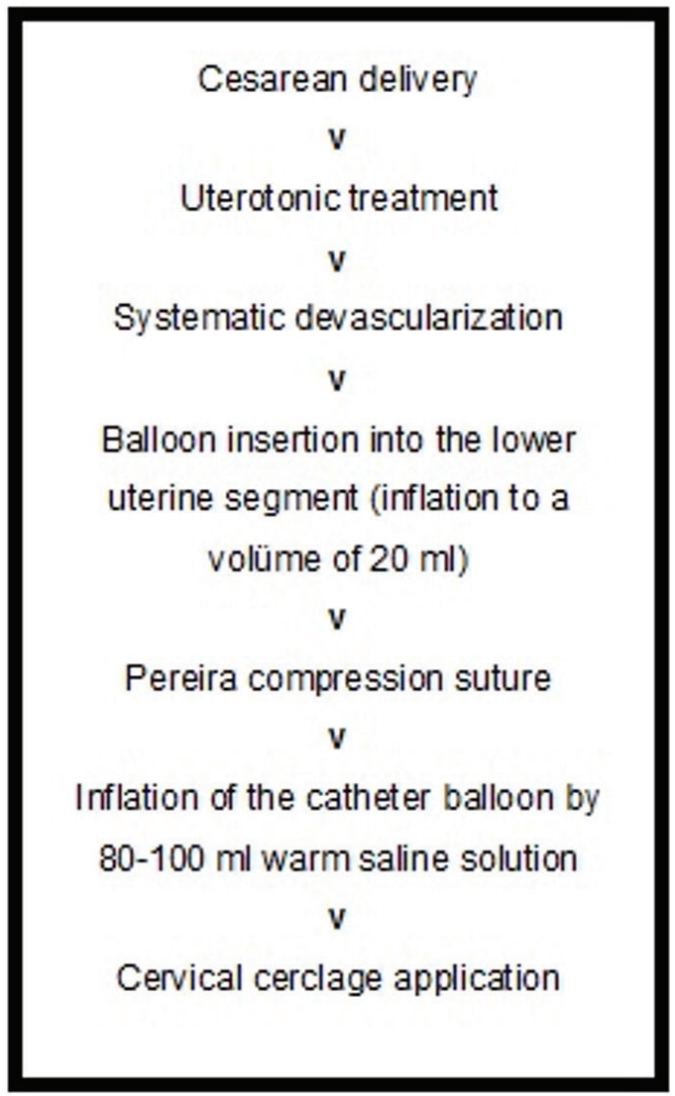

Figure 3. Intraoperative surgical procedure - flow chart
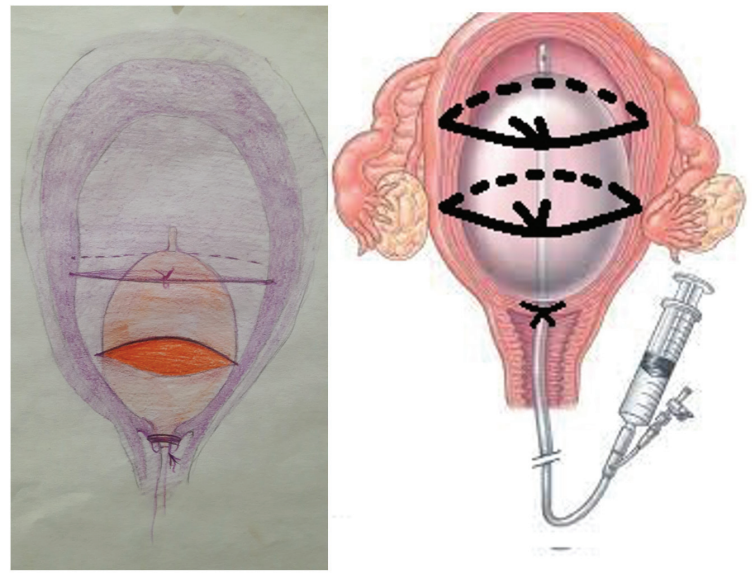

Figure 4. The illustration of surgical procedure 
Estimated blood loss was calculated with sponge counts and aspirated blood in the intraoperative period, and erythrocyte suspension and fresh frozen plasma were prepared. Erythrocyte suspension and fresh frozen plasma were administered intravenously according to the intraoperatively measured blood loss estimate.

Uterine perfusion was assessed using diffusion magnetic resonance imaging (MRI) (Siemens Magnetom Aera 1.5 Tesla, Berlin, Germany) (Contrast solution; Optimark) on the postoperative first day (Figure 5).

In hemodynamically stable patients, the Foley balloon in the uterine cavity was gradually lowered and pulled.

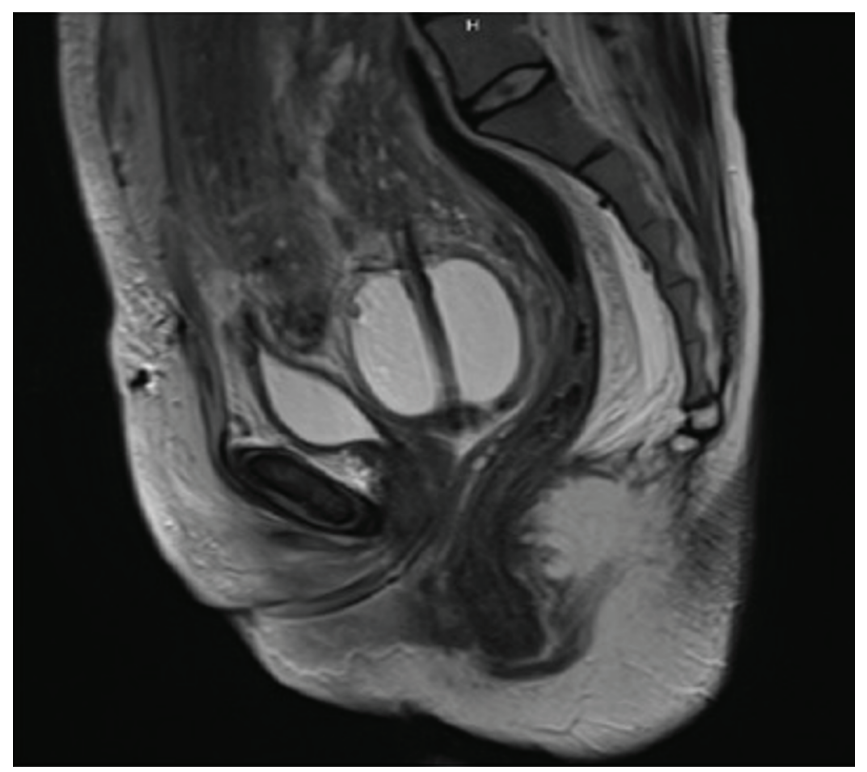

Figure 5. MRI view of the Foley catheter balloon in the lower uterine segment on the first postoperative day

MRI: Magnetic resonance imaging

\section{Results}

All included women who had been diagnosed as having PP, had placental invasion abnormalities proven via pathologic examination, namely PAS of varying degrees. Seventeen (44\%) of the 38 patients with PP and 12 with PP accreta spectrum underwent hysterectomy because they had at least two living children and did not desire further fertility. The remaining 13 patients with PP accreta spectrum were managed conservatively, six cases with posterior PP totalis benefit from uterine and bilateral hypogastric artery ligations. The seven patients featured in this report had continuing uterine bleeding despite uterine and hypogastric artery ligation. This lower segment uterine sandwich technique was performed to those with persistent uterine bleeding of PP percreta.

The remaining five patients had emergency cesarean delivery due to intensive vaginal bleeding.

The median (minimum-maximum) patient calendar age and gestational age at the time of delivery was 32 (range, 26-38) years and 35.5 (range, 33-38) weeks, respectively. Two women underwent Pomeroy's bilateral tubal ligation simultaneously. A mean of 6 (range, 4-11) U blood product transfusion was required in the intra- and post-operative period. The mean hospitalization period was 3.7 (range, 3-6) days and three women necessitated intensive care unit admission. None of the patients required a hysterectomy.

All included women reported regular menstruation at the end of a postoperative 1-year period. No patients experienced a morbid postoperative complication such as uterine necrosis or septicemia during the postoperative follow-up period. One patient in the second postoperative year and another woman in the third postoperative year conceived spontaneously, and both delivered uneventfully. One woman was lost to follow-up due to immigration. Characteristics, intra- and postoperative results,

Table 1. Patient characteristics and intra- and postoperative results

\begin{tabular}{|c|c|c|c|c|c|c|c|}
\hline & Patient 1 & Patient 2 & Patient 3 & Patient 4 & Patient 5 & Patient 6 & Patient 7 \\
\hline Age (yrs) & 31 & 37 & 33 & 26 & 28 & 36 & 38 \\
\hline Parity & 2 & 3 & 2 & 1 & 3 & 2 & 1 \\
\hline Previous cesarean delivery & $\mathrm{Y}$ & $\mathrm{Y}$ & $\mathrm{Y}$ & $\mathrm{Y}$ & $\mathrm{Y}(2)$ & $\mathrm{Y}$ & $\mathrm{Y}(4)$ \\
\hline Emergency cs & $\mathrm{Y}$ & $\mathrm{Y}$ & $\mathrm{Y}$ & No & No & $\mathrm{Y}$ & $\mathrm{Y}$ \\
\hline Gestasyonal age (wks) & 36 & 34 & 36 & 38 & 37 & 33 & 35 \\
\hline Hospitalization period (d) & 3 & 3 & 4 & 4 & 6 & 3 & 3 \\
\hline Maternal ICU admission & - & - & 1 & 1 & 3 & - & - \\
\hline Blood transfusion & 6 & 5 & 7 & 5 & 11 & 6 & 4 \\
\hline Complication & - & - & - & - & Bladder injury & - & - \\
\hline Intraop. diagnosis & P. percreta & P. percreta & P. percreta & P. percreta & P. percreta & P. percreta & P. increta \\
\hline Follow-up & $\mathrm{RM}$ & RM, BTL & $\mathrm{RM}$ & RM & $\mathrm{RM}$ & RM & RM, BTL \\
\hline
\end{tabular}


and follow-up results of all included women are presented in Table 1.

\section{Discussion}

The present study is the first to report the successful use of a novel low uterine sandwich technique, Caliskan's technique, which combines the systematic uterus devascularization, Foley's catheter balloon tamponade placement in the lower uterine segment, uterus compression suture, and cervical cerclage. Our data suggest that this novel technique achieved hemostasis with a high success rate in women with intractable PPH due to PP and PAS without compromising uterine blood flow and with no hysterectomy requirement.

Uterine sandwich techniques are surgical management methods that combine intrauterine balloon insertion and uterine compression sutures, aiming to control life-threatening obstetric hemorrhage ${ }^{(15,19)}$. A variety of uterine suturing methods have been defined in these uterine sandwich techniques, including B-Lynch et al. ${ }^{(20)}$, Hayman et al. ${ }^{(11)}$, or Cho et al. (21); nevertheless, all have pros and cons. Yoong et al. ${ }^{(17)}$ reported a series of 11 women presenting with uterine atony and PP, who were successfully managed with a uterine sandwich, employing Hayman sutures in nine and B-Lynch sutures in two women. However, both B-Lynch and Hayman sutures had some drawbacks; the longitudinal suture threads tend to slide off laterally or medially or the uterine body tends to fold anteriorly ${ }^{(12,22)}$. Matsubara et al. ${ }^{(23)}$ reported a novel suture technique, namely the Matsubara-Yano suture, which was used concomitantly with an intrauterine balloon in 5 cases of PP. They claimed that this novel suturing method overcame the drawbacks of the former sutures because it transfixed the uterine fundus with longitudinal sutures and included transverse sutures laterally to prevent the longitudinal sutures from sliding off. Although similar, Caliskan's technique differs from the Matsubara-Yano uterine sandwich in that our technique employs systematic devascularization and stabilizes the Foley's catheter balloon to the lower uterine segment in a pressurized manner uing the Pereira suture from the top and by the cervical cerclage suture from below. This measure helps to achieve hemostasis in two ways; (i) it stabilizes the Foley's catheter balloon within the lower uterine segment where the PP and PAS bleeding occurs and does not allow it to slip downwards to the vagina, (ii) it increases intramyometrial pressure within the lower segment more efficiently, further helping to reduce the hemorrhage by collapsing the intramyometrial vessel openings. Uterine compression sutures have been reported to be related to some complications, including uterine necrosis and uterine synechiae ${ }^{(24,25)}$. Cho sutures are reported to be associated with these complications more frequently. It has been extrapolated that these complications might be associated with "compression tightness" and "uterine penetration"(26). Lodhi et al. ${ }^{(27)}$ reported uterine necrosis following application of B-Lynch compression suture and intrauterine balloon tamponade. By contrast, Yoong et al. ${ }^{(17)}$ expressed that women undergoing a uterine sandwich procedure experienced lower rates of uterine necrosis as compared with those who received compression sutures only, possibly due to allowing the pressure exposed on the uterine wall to spread on a wider surface area ${ }^{(23,28)}$. They also suggested checking for signs of "uterine blanching" as a subjective measure of the balloon achieving its tamponade effect. In our clinical series, we assessed uterine blood supply using diffusion MRI on the first postoperative day, which revealed no findings of abnormal vascularization and diffuse or local loss of endomyometrial blood supply.

The Pereira suture was first described in a case series of seven women with PPH and consists of numerous transverse and longitudinal continuous sutures, in which a thread is placed in a circular fashion around the uterus ${ }^{(18)}$. This technique has the merit that it lacks uterine cavity penetration, thus is associated with a lower incidence of postoperative infection. Also, Pereira suture does not slide off laterally or medially, which is one of the main drawbacks of B-Lynch and Hayman sutures. Moreover, we experienced that the Pereira suture has been effective in achieving hemostasis via providing a higher pressure by compressing myometrial fibers in the uterine lower segment and, in turn, reducing its volume.

Systematic pelvic devascularization is an effective surgical method to control persistent PPH due to PP or PAS in women wishing to preserve their uterus and includes ligation of the uterine, utero-ovarian, and internal iliac arteries. Bilateral ligation of internal iliac arteries was reported to decrease the pulse pressure in the distal artery by as much as $85 \%$, whereas blood flow is reduced by at most $50 \%{ }^{(29)}$. Thus, we incorporated this surgical procedure, which we consider to accelerate the plug formation within the site of bleeding, into our technique.

\section{Study Limitations}

Simultaneous use of intrauterine balloon catheter with B-Lynch suture has been defined by several groups to manage women with PPH due to uterine atony ${ }^{(15,16)}$. In all these cases, hemorrhage was due to atonic uterine myometrium; however, in all the PPH cases presented here, the etiologic factor was PP in addition to PAS. Given the lower uterine origin of PP hemorrhage, we stabilized the catheter balloon within the lower segment of the uterus. Similarly, Matsubara et al. ${ }^{(26)}$ claimed that uterine compression sutures achieved better hemostasis in upper segment hemorrhage, but intrauterine balloon placement could be more appropriate in bleeding from the lower segment. Moreover, they stated that balloon placement in the lower segment might induce a uterine body contraction, possibly via neuronal reflex, which, in turn, achieves hemostasis.

\section{Conclusion}

The novel Caliskan's uterine sandwich method appears to be a feasible and minimally invasive procedure in intractable $\mathrm{PPH}$ due to PP and/or PAS, particularly in women who wish to preserve their future fertility, without major morbidity, 
hysterectomy necessity, and maternal mortality. However, the efficacy and safety of the technique must be tested and confirmed in large-scale clinical trials or case series.

\section{Ethics}

Ethics Committee Approval: The study was performed in accordance with the ethical standards for human research established by the Declaration of Helsinki and Good Clinical Practice guidelines and approved by the local Ethics Committee of Bahcesehir University School of Medicine.

Informed Consent: All patients provided written informed for the application of this technique.

Peer-review: Externally peer-reviewed.

\section{Authorship Contributions}

Surgical and Medical Practices: E.Ç., B.A., Concept: B.A., Design: E.Ç., Data Collection or Processing: Y.C., Analysis or Interpretation: C.K., Literature Search: C.K., Writing: E.Ç., Y.C. Conflict of Interest: The authors report no conflict of interest. Financial Disclosure: Authors have no financial interests about the research

\section{References}

1. Crane JM, Van den Hof MC, Dodds L, Armson BA, Liston R Maternal complications with placenta previa. Am J Perinatol 2000;17:101-5.

2. Grobman WA, Gersnoviez R, Landon MB, Spong CY, Leveno KJ, Rouse DJ, et al. Pregnancy outcomes for women with placenta previa in relation to prior number of cesarean deliveries. Obstet Gynecol 2007;110:1249-55.

3. Knight M, UKOSS. Peripartum hysterectomy in the UK: management and outcomes of the associated hemorrhage. BJOG 2007;114:1380-7.

4. Khan KS, Wojdyla D, Say L, Gulmezoglu AM, Van Look PF. WHO analysis of causes of maternal death: a systematic review. Lancet 2006;367:1066-74.

5. Wagaarachchi PT, Graham WJ, Penney GC, McCaw-Binns A, Yeboah Antwi K, Hall MH. Holding up a mirror: changing obstetric practice through criterion-based clinical audit in developing countries. Int J Gynaecol Obstet 2001;74:119-30.

6. Fan D, Xia Q, Liu L, Wu S, Tian G, Wang W, et al. The incidence of postpartum hemorrhage in pregnant women with placenta previa: a systematic review and meta-analysis. PLoS One 2017;12:e0170194. doi: 10.1371/journal.pone.0170194.

7. Kollmann M, Gaulhofer J, Lang U, Klaritsch P. Placenta praevia: incidence, risk factors and outcome. J Matern Fetal Neonat Med 2016;29:1395-8

8. Mastrolia SA, Baumfeld Y, Loverro G, Yohai D, Hershkovitz R, Weintraub AY. Placenta previa associated with severe bleeding leading to hospitalization and delivery: a retrospective populationbased cohort study. J Matern Fetal Neonat Med 2016;29:3467-71.

9. Le Ray C, Audibert F, Dubois J. Prophylactic balloon occlusion of the internal iliac arteries to treat abnormal placentation. Am J Obstet Gynecol 2008;199:e11-2; author reply e12-3. doi: 10.1016/j. ajog.2008.03.057.

10. Zwart JJ, Dijk PD, van Roosmalen J. Peripartum hysterectomy and arterial embolization for major obstetric hemorrhage: a 2-year nationwide cohort study in the Netherlands. Am J Obstet Gynecol 2010;202:150.e1-7. doi: 10.1016/j.ajog.2009.09.003.
11. Hayman RG, Arulkumaran S, Steer PJ. Uterine compression sutures: surgical management of postpartum hemorrhage. Obstet Gynecol 2002;99:502-6.

12. Matsubara S. A new compression suture to prevent "uterine sandwich" from sliding off. Acta Obstet Gynecol Scand 2012;91:638-9.

13. Dildy GA 3rd. Postpartum hemorrhage: new management options. Clin Obstet Gynecol 2002;45:330-44.

14. Al-Zirqi I, Vangen S, Forsen L, Stray-Pedersen B. Prevalence and risk factors of severe obstetric haemorrhage. BJOG 2008;115:126572.

15. Danso D, Reginald P. Combined B-lynch suture with intrauterine balloon catheter triumphs over massive postpartum haemorrhage. BJOG 2002;109:963.

16. Nelson WL, O'Brien JM. The uterine sandwich for persistent uterine atony: combining the B-Lynch compression suture and an intrauterine Bakri balloon. Am J Obstet Gynecol 2007;196:e9-10. doi: 10.1016/j.ajog.2006.10.887.

17. Yoong W, Ridout A, Memtsa M, Stavroulis A, Aref-Adib M, Ramsay-Marcelle $\mathrm{Z}$, et al. Application of uterine compression suture in association with intrauterine balloon tamponade ("uterine sandwich') for postpartum hemorrhage. Acta Obstet Gynecol Scand 2012; 91:147-51.

18. Pereira A, Nunes F, Pedroso S, Saraiva J, Retto H, Meirinho M. Compressive uterine sutures to treat postpartum bleeding secondary to uterine atony. Obstet Gynecol 2005;106:569-72.

19. Price N,Whitelaw N, B-Lynch C. Application of the B-Lynch brace suture with associated intrauterine balloon catheter for massive haemorrhage due to placenta accrete following a second trimester miscarriage. J Obstet Gynaecol 2006; 26:267-8.

20. B-Lynch C, Coker A, Lawal AH, Abu J, Cowen MJ. The B-Lynch surgical technique for the control of massive postpartum haemorrhage: an alternative to hysterectomy? Five cases reported Br J Obstet Gynaecol 1997;104:372-5.

21. Cho JH, Jun HS, Lee CN. Hemostatic suturing technique for uterine bleeding during cesarean delivery. Obstet Gynecol 2000;96:12931

22. Mondal PC, Ghosh D, Santra D, Majhi AK, Mondal A, Dasgupta S. Role of Hayman technique and its modification in recurrent puerperal uterine inversion. J Obstet Gynaecol Res 2012;38:438-41.

23. Matsubara S, Kuwata T, Baba Y, Usui R, Suzuki H, Takahashi H, et al. A novel 'uterine sandwich' for haemorrhage at caesarean section for placenta praevia. Aust N Z J Obstet Gynaecol 2014;54:283-6.

24. Joshi VM, Shrivastava M. Partial ischemic necrosis of the uterus following a uterine brace compression suture. BJOG 2004;111:27980 .

25. Wu HH, Yeh GP. Uterine cavity synechiae after hemostatic square suturing technique. Obstet Gynecol 2005;105:1176-8.

26. Matsubara S, Yano H, Ohkuchi A, Kuwata T, Usui R, Suzuki M. Uterine compression sutures for postpartum hemorrhage: an overview. Acta Obstet Gynecol Scand 2013;92:378-85.

27. Lodhi W, Golara M, Karangaokar V, Yoong W. Uterine necrosis following application of combined uterine compression suture with intrauterine balloon tamponade. J Obstet Gynaecol 2012;32:30-1.

28. Garofalo M, Posner GD. Towel uterus model for uterine compression sutures technical skills training: a review of literature and development of a performance rubric. Cureus 2018;10:e2725. doi:10.7759/cureus.2725.

29. Burchell RC. Physiology of internal iliac artery ligation. J Obstet Gynaec Br Commonw 1968;75:642-51. 